\author{
Serhii Zubchenko \\ National Institute for Strategic Studies (Kyiv, Ukraine) \\ https://orcid.org/oooo-0oo1-6909-7881 \\ e-mail: zubchenko@niss.gov.ua
}

\title{
STRATEGIC ROLE OF POLITICAL AND LEGAL VALUES IN INTERNATIONAL RELATIONS OF THE MODERN HYBRID WARFARE ERA
}

\begin{abstract}
The relevance of the article determines by urgent problems of the global diplomatic agenda, in particular, concerning the international legal response to the Russian military aggression against Ukraine and acts of state terrorism all around the world carried out by Russia within its doctrine of hybrid war. After the end of Yugoslav wars and up until 2014, the threat of full-scale military conflict in European continent was mistakenly evaluated as low, while the other threats (in particular, associated with globalization) considered to be more dangerous. However, the permission to use armed force in Ukraine, unanimously given to V. Putin by the Federation council of Russia on March 1, 2014 and the following events in Ukrainian Crimea and Donbas regions crushed the global order established after the fall of USSR and opened a horrifying terroristic «Pandora's box» in the very heart of Europe.

As a result of the study, political and legal proposals and recommendations were determined. Considerations regarding the role of trust as a vital element of interstate relations, the lack of which provokes conflicts, leads to the encapsulation of states, making it impossible for them to achieve sustain and progressive development and to solve important common problems, are substantiated.

As a conclusion in this context, the necessity to ensure strict adherence of the principles of international law as the «rules of the game» of the geopolitical club and the «red lines», violating of which activates uncontrolled global scale processes, is highlighted. It is also necessary to ensure prompt response to apparent violations of international law that threaten international peace and global security. In addition, the urgent need to preserve international sanctions against the aggressor country - Russian Federation - and entities, individuals and groups, affiliated with the Putin's regime, is insisted.

Key words: Russian aggression against Ukraine, international law, political and legal values, principles of international law, foreign policy, hybrid war
\end{abstract}




\section{Зубченко Сергій Олександрович}

Національний Інститут стратегічних досліджень (м. Київ, Украӥна)

https://orcid.org/oooo-ooo1-6909-7881

e-mail: zubchenko@niss.gov.ua

\section{СТРАТЕГІЧНА РОЛЬ ПОЛІТИКО-ПРАВОВИХ ЦІННОСТЕЙ У МІЖНАРОДНИХ ВІДНОСИНАХ СУЧАСНОЇ ДОБИ ГІБРИДНИХ ВІЙН}

\section{Резюме}

Актуальність статті визначається нагальними проблемами світового дипломатичного порядку денного, зокрема щодо міжнародно-правового реагування на російську військову агресію проти України та актів державного тероризму в усьому світі, здійснюваних Росією в рамках ії доктрини гібридної війни. Після закінчення югославських воєн і до 2014 року загроза повномасштабного військового конфлікту на європейському континенті помилково оцінювалася як низька, тоді як інші загрози (зокрема, пов'язані з глобалізацією) вважалися більш небезпечними. Однак дозвіл на застосування збройної сили в Україні, одноголосно наданий В. Путіну Радою федерації Росії 1 березня 2014 р., та наступні події в українському Криму та на Донбасі, зруйнували глобальний порядок, встановлений після падіння СРСР, і відкрили жахливу терористичну «скриньку Пандори» в самому серці Європи.

Завдання дослідження - дати бачення суттєвого місця політичних та правових цінностей (зокрема, принципів міжнародного права) у сучасній системі міжнародних відносин, що переживає важкі часи з огляду на сучасні безпекові, політичні та пандемічні загрози.

Методи та методологічний апарат дослідження базуються на принципах органічного поєднання філософських, політичних, загальнонаукових та спеціальних методів, єдності політико-правової науки та гносеологічного аналізу. Окрім традиційних та іманентних для кожного наукового дослідження методів (аналіз, синтез, дедукція, індукція, узагальнення, екстраполяція тощо), для досягнення мети дослідження викорис- 
товувались структурно-функціональний, порівняльно-ретроспективний, герменевтичний методи та методи математичного моделювання.

В результаті дослідження були визначені політико-правові пропозиції та рекомендації. Обгрунтовано міркування щодо ролі довіри як життєво важливого елемента міждержавних відносин, відсутність яких провокує конфлікти, веде до інкапсуляції держав, унеможливлюючи досягнення ними стійкого та поступального розвитку та вирішення важливих спільних проблем. Як висновок у цьому контексті підкреслюється необхідність забезпечити неухильне дотримання принципів міжнародного права як «правил гри» геополітичного клубу та «червоних ліній», порушення яких активізує неконтрольовані глобальні процеси. Необхідно також забезпечити оперативне реагування на очевидні порушення міжнародного права, що загрожують міжнародному миру та глобальній безпеці. Крім того, наполягається на винятковій необхідності збереження міжнародних санкцій проти країни-агресора - Російської федерації-та афілійованих із режимом Путіна юридичних/фізичних осіб і груп.

Ключові слова: російська військова агресія проти України, міжнародне право, політико-правові цінності, принципи міжнародного права, зовнішня політика, гібридна війна.

\section{Introduction}

Until recently, issues of political and legal values, principles and senses have been rather the subject of specialized theoretical and methodological discussions of legal professionals than a topical practical issue of the international agenda. However, now - quite unexpectedly for many-legal and axiological issues, have acquired a new sound. Moreover, this is not about the moral and ethical aspect (although it is also important), but about quite pragmatic, practical things - for example, about their significant impact on the security situation. It has suddenly become clear that even in the XXI century, in the era of realpolitik, dominant geopolitical cynicism and hybrid wars, the principles of international law are still a major factor in ensuring global stability and peace.

But how some legal abstractions and symbolic conventions, which were the result of compromises from the very beginning (as they were enshrined at a high international legal level of the UN Charter, the Declaration on Principles of International Law concerning Friendly Relations and Co-operation among States in accordance with the Charter of the United Nations of 1970, the Final Act of the Conference on Security and Cooperation in Europe in 1975), can significantly affect something in the modern world? It seemed quite logical that, with the collapse of the USSR and the end of irreconcilable global ideological confrontation, economic values as more specific, pragmatic and understandable for everyone will become a «universal protocol» of interstate communication, the best guarantor of predictability and stability in international relations. 
However, everything happened exactly the opposite. The best illustration of this is the ongoing - since 2014 - armed aggression of the Russian Federation against Ukraine, with an attempt to illegally annex the Ukrainian Crimea and the occupation of the certain areas of Donetsk and Luhansk oblasts (ORDLO), and a hybrid war against the entire civilized world. By the end of 2020 the death toll of the Russian-Ukrainian war (which already lasts longer than the WW2) is about 14,000 killed, up to 31,000 wounded and more than 1,500,000 internally displaced persons [1]. In addition, Russia illegally holds more than 200 Ukrainian citizens (both military and civilian) - and the number is constantly growing due to arbitrary detentions on the occupied territories of both the ORDLO and the Crimea, while some of the hostages are being held in inhumane conditions and systematically subjected to torture and ill-treatment. Also due to the activities of the Russian occupation forces, Ukraine now is among the countries with the highest number of victims and injuried of mines [2] and the area of mined areas in Ukraine is estimated at more than $7,000 \mathrm{~km}^{2}$ - that is the area of five Londons, seven Berlins or fourteen Budapests.

In our view, it is the unjustified sacrifice of political and legal values and principles to economic expediency and particular political interests that has largely led to the current crisis in the international security system - perhaps the largest one since Hitler's late 1930s «gathering of lands» in Europe.

\section{Methods}

Given that the research topic is interdisciplinary (philosophy, political science and international law), methods and methodical tools of the study are based on the principles of organic combination of philosophical, political, general scientific and special methods, unity of political and legal science and epistemological analysis. In addition to traditional and immanent for each scientific research methods (such as analysis, synthesis, deduction, induction, generalization, extrapolation, etc. ), to achieve the objective of the study structural-functional, comparative-retrospective, hermeneutic methods were used. The results of the use of mathematical modeling methods within the framework of game theory are also presented (to highlight the important role of trust in games with non-zero winnings, a variety of which can be considered international relations).

\section{Results}

The famous British researcher E. Lucas back in 2008 wrote that «if you believe that capitalism is a system in which money weighs more than freedom, you are doomed when people who do not believe in freedom attack using money. Russia has noticed that the weakest link in the Western approach to life is the neglection of the moral and ethical basis of capitalism: if only money weighs, then why is the Kremlin's money worse than anyone else's?» [3, p. 186]. However, at that time his warnings just were not properly perceived by the 
international political establishment. Even after the more than eloquent Munich2007, Georgia-2008, and outright reversal to the Soviet foreign policy rhetoric and methodology all Russian antics were looked upon indulgently, until the elderly Russian Fuhrer from «Petersburg's backyard» started a war in the very geographical center of Europe. Looks like winning the Sochi-2014 Olympics (as we know, exclusively by the large-scale state-supported sports doping system) finally ripped off his roof.

Nevertheless, even after six years since the beginning of the RussianUkrainian war not everyone had the courage to call a spade a spade, as, for example, the US Special Representative for Ukraine K. Walker did («There is almost no difference between Crimea and Donbas... This is a Russian invasion, a Russian occupation of the territory ... which is illegal» [4]; «The so-called «LPR» and «DPR» are entities that were created by Russia to generate political reality in order to help disguise the role of Russia and strengthen the ongoing conflict» [5]). Some actors in diplomatic circles still suggest forgetting the bitter historical lessons of the policy of «appeasement of the aggressor» of the last century, calling for «understanding and forgiveness» of mugger-state-Russia - and its obsessive leader, no matter how convincing the evidences of its direct armed aggression and war crimes on the territory of Ukraine are (from cross-border artillery shelling and direct entry of regular military troops into Ukraine - to the downing of a civilian Boeing-777 flight MH-17 of Malaysian Airlines and atrocities against the local population of Donbas).

It should be acknowledged that the temptation to push the issue of illegal annexation attempt of Crimea and the ongoing Russian-Ukrainian war in Donbas to the background on the international political agenda is quite significant. Russian and pro-Russian lobbyists mainly appeal to pragmatic-economic (that sanctions against Russia indirectly cause some damage to the economy of the states that imposed them) and security (that there are more fundamental threats to international peace and security now, which allegedly can not be effectively neutralized without Russia's participation) factors. However, such arguments cannot be considered convincing for the following reasons.

Firstly, a country for which its imperial whims weigh more than its signed international legal obligations will never be a reliable and predictable economic partner (especially since this «partner» perceives the economy only as another tool to realize its revanchist ambitions). Therefore, those who try to look at relations with Russia solely through the prism of profits or rationalism are making a huge methodological mistake. This is either the highest level of naivety or deliberate sabotage in the interests of the aggressor country. Trade deals with a subject whose leadership considers the collapse of the USSR «the greatest geopolitical catastrophe of the XX century», has a pronounced criminal mindset and openly despises legal values, publicly declaring aggressive chauvinistic and revanchist intentions towards the territories of neighboring sovereign states (just 
recall Putin's Address to the Federal Assembly of March 1, 2018, when he directly called the territories of the former Soviet republics «the territory of Russia»), are a priori very questionable. In the short-term run this may have some economic benefits, but in the medium- and long-term run it may result in huge losses for the contingent beneficiary. The case of Ukraine, which had strategic partnership with Russia before the war, is the perfect example. However, if then the «Kremlin patient» only proclaimed pathetic declarations or boorish semi-fascist jokes, now he implements them, including by force of arms.

But the point here is not only some moral and ethical estimations or categorical mismatch of axiological coordinate systems. Secondly, it is now well known that Russia is artificially creating centers of instability and terrorism around the world to put pressure on certain states and the international community, and then «kindly» offer its help, forcing the victims to dialogue to resolve these problems. There are many examples, even excluding the Russian war against Ukraine: planning terrorist attacks in Norway, France and Montenegro, deliberately inciting the war in Syria, supplying weapons to Libya, cooperation with the North Korea (bypassing the UN sanctions). Compared to these "peacekeeping activities», Russian hackers and bots' interference in some foreign elections and referendums seems to be just child's play (as well as violent measures against its own people - the opposition, the media, civil society institutions, etc. ). However, from a legal point of view, all these actions of Russia fall quite clearly under the definition of state terrorism, given in the Geneva Declaration on Terrorism in 1987 [6]. Thus, the one who calls to solve security problems of international terrorism together with Russia, in fact calls for negotiations and cooperation with terrorists themselves, which is absolutely unacceptable and will only encourage Russia to continue its criminal activities.

Thirdly, and this is the most important, Russia's illegal actions have set a colossal international precedent, which could not simply be put under the cloth even if desired, as its consequences goes far beyond regional or continental security issues. And it is not a matter of some political assessments or historical parallels. The key points here are: 1) which state became the victim of aggression - a state that previously voluntarily, under international security guarantees, renounced its nuclear arsenal (the third largest in the world!) and joined the Treaty on the Non-Proliferation of Nuclear Weapons; 2) who was the aggressor - the Russian Federation, a country that was a strategic partner and one of the international guarantors of Ukraine's security under the Budapest Memorandum; 3) what were the actions of other states, in particular, the signatories of the Budapest Memorandum-they were completely sluggish, formal and unconvincing, and thus could not prevent the attempt of illegal annexation of Crimea and further Russian military invasion in Donbas. More than a telling signal even for the most ardent international «sloops»: abandonment of weapons of mass destruction is outright stupidity, no one can be trusted (even strategic partners 
and «guarantors»), and all agreements and treaties (even the highest level) are just «paper tigers» that will not save you from military aggression if you do not take care of your own armed forces. What does this mean in practice? A new round of the global arms race (not only conventional but also weapons of mass destruction) and the escalation of international tensions and mutual mistrust (not to mention the growing considerable skepticism about the existing system of international organizations and international law). And these trends are already embodied in very specific figures (for example, the growth of arms trade).

All mentioned above has a direct bearing on the role of political and legal values (in particular, the principles of international law) in ensuring global stability and peace. And the explanation for this is very simple.

Mathematical modeling performed within the framework of game theory proves that in games with non-zero winnings the end result of the game largely depends on such an intangible and seemingly ephemeral factor as trust. Moreover, if in the short term the advantage in the game is gained by players who are prone to fraud and insidiousness, in the long run those who build their strategy on trust and play honestly will win [7]. This is confirmed in the works of R. Axelrod. However, stable trust cannot be formed in conditions when the game does not have clear and inviolable rules, and the player cannot be sure of the results of the interaction. This is even more relevant in today's information world, in which it is almost impossible to hide something so that it does not become apparent, sooner or later.

In modern international relations such «rules of the game» are the fundamental political and legal values embodied in the principles of international law. That is why these ephemeral and «impractical», at first glance, idealistic categories and meanings are in fact more than serious global security factors. Crossing these «red lines» could lead to unpredictable «chain reaction», heavy international consequences, or even global geopolitical turbulence, which we are witnessing today. That is why the protection of the "rules of the geopolitical club», ensuring strict adherence to the principles of international law is in the common interests of all actors, the cause of the entire world community.

Of course, experts can rightly point out that trust between states (including Western) was a rather scarce resource even before 2014. Similarly, the observance of the principles of international law by countries has not always been impeccable. However, prior to Russian aggression against Ukraine and Russia's occupation of the "21st-century Sudetenland» (Crimea) and parts of Donbas (ORDLO), there were no events in postwar Europe that posed such a clear and present threat to the existing international legal system and legal order.

That is why the attempt of illegal annexation of Crimea and further Russia's armed aggression against Ukraine cannot be removed from the international agenda - until full restoration of Ukraine's territorial integrity and the legal 
punishment of the aggressor (as it was with Hitler's Reich). It is not a question of someone's subjective attitude to Ukraine or Russia - it is a question of objective preservation of the international legal order (despite all its relativeness) and prevention of similar international war crimes; a question of global collective self-preservation instinct. There is no - and cannot be - any alternative to this, just as there is no and cannot be any alternative to the principle of unavoidability of punishment as a universal safeguard in criminal law. After all, the virus of international legal impunity is extremely highly contagious and its spread from regional to larger continental and global scale can be stopped only by strict and decisive joint actions.

\section{Conclusions}

The global geopolitical turbulence of the last six years has raised with new urgency the question of the place and role of political and legal values in modern international relations. It can be argued that the widespread indulgent attitude to the principles of international law (in fact, sacrificing them to economic benefits and political considerations), unwillingness to respond harshly and consistently to their outright violations created the basis for Russia's illegal annexation and the ongoing since 2014 armed aggression of the Russian Federation in Donbas (with the actual occupation of ORDLO and the establishment of puppet «proxy republics» there to disguise Kremlin's actions). But the worst thing is that the criminalized thinking of the Russian leadership has gone beyond the traditional symbolic sphere or just «demonstration acts» (in military terminology) and now poses a clear and present threat not only to Ukraine, but to the entire existing international legal system. They cynically exploit the institutional and functional weakness of the current system of international organizations (including the UN system) as a consensus and preventive mechanism, deliberately driving the West into a «rule trap», sowing entropy and undermining the already imperfect trust-a crucial common denominator of interstate relations-between international actors.

That is exactly why this case is not a matter of morality or ethics alone. It is also incorrect to see it as only a problem of bilateral Russian-Ukrainian relations or a threat only to regional security. Without exaggeration, the ability of the international community to defend the principles of international law, grossly violated by Russia, is a matter of survival of the entire modern international legal system.

To prevent the escalation of existing negative geopolitical trends to the level of uncontrolled, destructive processes, it is necessary to ensure general compliance with the key points listed below:

\section{Inviolability of the fundamental principles of international} law. Political and legal values are the critical elements of modern international political life, the reference points of the international coordinate system, its «universal protocol» and axiological basis. That is why they are «red lines» that 
cannot be ignored even for achieving a significant situational gain. Geopolitical Machiavellianism, despite all its advantageous appeal, has an extremely limited shelf life in a globalized information society. It can provide certain benefits only in the short term, but in the long term it is a catalyst for colossal negative trends that can greatly harm not only the object against which it is directed and the entity that used it, but also the «third parties» (regardless of whose side - the assumed «claimant» or the assumed «defendant»-they take) and the environment in which they all exist. In short, it is very easy for one to release the genie of international legal nihilism from a bottle, but it is very hard even for the whole world to drive it back. Otherwise, the geopolitical «club of gentlemen» will turn into a «fight club» without rules, an endless «war of all against all», which mean a huge reversal in international relations, rolling back to the Middle Ages (in the worst sense of the term).

\section{Prompt response to apparent violations of international} law that threaten international peace and global security. The Kremlin's adventurists have clearly demonstrated the serious consequences of a lack of international consensus and procrastination on issues that need to have quick and drastic reaction. Therefore, a critical issue is the development of new international response formats that would provide an opportunity to counteract in consolidate way the clearly illegal and inadequate actions of the offending state. An integral element of this is stripping away rose-tinted glasses and illusions about the allegedly rationalist motives and actions of the Russian leadership, as well as developing a psychological readiness for a real armed repulse of military aggression. The indisputable right of each state to have its own political culture and national interests should in no way be an excuse for starting a war against its neighbors or other sovereign states.

\section{Inevitability of legal liability for violation of international}

law. Just eliminating the consequences of international legal impunity and irresponsibility is not enough, it is necessary to remove their causes by creating an effective anti-motive for such actions. The leadership of the aggressor state, like any criminals, must realize absolutely clearly that they will not be able to avoid responsibility in any way (although the punishment may not be immediate). After all, crimes against humanity, given their nature and scale and in contrast to ordinary crimes, have no statute of limitations.

Insofar as the violator is a small (in terms of share in global GDP) and technologically dependent, but still a large country with significant nuclear potential and a permanent member of the UN Security Council, the economic levers are the top priority - exactly those that once led to the collapse of the Soviet Union, which was incomparably stronger than today's Russia. In this context, the most important issue is the rapid neutralization of Russia's «hydrocarbon weapons», which have been used as an effective means of political pressure on energy-vulnerable European countries (including Ukraine). It should also be 
consider that Russia's economy and corrupt elites are objectively much more vulnerable to Western sanctions than the corresponding Soviet ones. Therefore, these practices have every chance to achieve the goal in a particular situation and become an effective demotivator for all other potential offenders.

The question of lifting economic sanctions on the aggressor state can be raised only after the full restoration of Ukraine's territorial integrity: the withdrawal of Russian troops from Donbas, the liquidation of Russian puppet pseudo-republics in ORDLO and the return of illegally annexed Crimea. Without this, its pedagogical penal effect will be nullified.

\section{References}

1. Report on the Human Rights Situation in Ukraine (16 November 2019 to 15 February 2020). (2020). Office of the United Nations High Commissioner for Human Rights. URL: https://www. ohchr. org/Documents/Countries/UA/29thReportUkraine_EN.pdf.

2. Saakov, Valerii (2020). Ukraine is Among World Leaders in Landmines Casualties. Deutsche Welle. URL: https://p. dw. com/p/3TTPe [in Ukrainian].

3. Lucas, Edward (2009). The New Cold War. Putin's Russia and the Threat to the West. Kyiv: Tempora [in Ukrainian].

4. Volker: Russia'sCreated «DPR» and «LPR» MustbeLiquidated - They do not Comply With the Constitution of Ukraine (video). (2018). YHIAH. URL: https://www. unian. ua/politics/10029467-volkerstvoreni-rf-dnr-i-lnr-mayut-buti-likvidovani-voni-ne-vidpovidayutkonstituciji-ukrajini-video. html [in Ukrainian].

5. Kurt Volker: The Full Transcript. (2017). Politico Magazine. URL: https://www. politico.com/magazine/story/2017/11/27/kurt-volkerthe-full-transcript-215868

6. The Geneva Declaration on Terrorism / UN General Assembly Doc. A/42/307, 29 May 1987, Annex. International Progress Organization. URL: http://www. i-p-o. org/GDT.HTM

7. The Evolution of Trust. (2017). Nicky Case. URL: http://ncase. me/ trust/

\section{Список посилань}

1. Report on the Human Rights Situation in Ukraine (16 November 2019 to 15 February 2020). Office of the United Nations High Commissioner for Human Rights. URL: https://www. ohchr. org/ Documents/Countries/UA/29thReportUkraine_UA.pdf

2. Сааков Валерій. Україна - серед лідерів у світі за кількістю жертв мін. Deutsche Welle. URL: https://p. dw. com/p/3TTPe

3. Лукас Е. Нова холодна війна. Як Кремль загрожує і Росії, і Заходу. Київ: Темпора, 2009. 488 с. 
4. Волкер: створені РФ «ДНР» і «ЛНР» маютьбутиліквідовані-вони не відповідають Конституції України (відео). УHIAH. URL: https://www. unian. ua/politics/10029467-volker-stvoreni-rf-dnr-ilnr-mayut-buti-likvidovani-voni-ne-vidpovidayut-konstituciji-ukrajini-video. html

5. Kurt Volker: The Full Transcript. Politico Magazine. URL: https:// www. politico. com/magazine/story/2017/11/27/kurt-volker-thefull-transcript-215868

6. The Geneva Declaration on Terrorism / UN General Assembly Doc. A/42/307, 29 May 1987, Annex. International Progress Organization. URL: http://www. i-p-o. org/GDT.HTM

7. The Evolution of Trust. Nicky Case. URL: http://ncase. me/trust/

Стаття надійшла до редакції 20.10.20

(C) Зубченко C. O., 2020 